\title{
Effects of past and current management practices on crop yield and nitrogen leaching-a comparison of organic and conventional cropping systems
}

\author{
C. STARK $^{1}$ \\ L. M. CONDRON ${ }^{2}$ \\ A. STEWART ${ }^{3}$ \\ H. J. DI ${ }^{2}$

M. O’CALLAGHAN ${ }^{4}$
${ }^{1}$ Teagasc
Johnstown Castle
Wexford, Ireland
email: christine.stark@ teagasc.ie
${ }^{2}$ Agriculture and Life Sciences Division
P.O. Box 84
Lincoln University
Canterbury, New Zealand
${ }^{3}$ National Centre for Advanced Bio-protection
Technologies
P.O. Box 84
Lincoln University
Canterbury, New Zealand
${ }^{4}$ AgResearch
P.O. Box 60, Lincoln
Canterbury, New Zealand

\begin{abstract}
Farming practices can have significant effects on important soil processes, including nitrogen $(\mathrm{N})$ dynamics and nitrate leaching. A lysimeter experiment was conducted to determine differences in $\mathrm{N}$ leaching resulting from past and current crop management practices. Intact monolith lysimeters $(50 \mathrm{~cm}$ diam. $\times 70 \mathrm{~cm}$ deep) were taken from sites of the same soil type that had either been under long-term organic or conventional crop management. These were then managed according to established organic and conventional practices over $2 \frac{1}{2}$ years using the same crop rotation (barley (Hordeum vulgare L.), maize (Zea mays L.), rape (Brassica napus L. ssp. oleifera) plus a lupin green
\end{abstract}

H06015; Online publication date 6 July 2006 Received 6 March 2006; accepted 20 April 2006 manure (Lupinus angustifolius L.)) and two fertiliser regimes, resulting in four treatments based on soil management history and current fertilisation strategy. Dry matter yield of each crop was determined after harvest and leachates were collected after significant rainfall events and analysed for total mineral $\mathrm{N}$ concentrations. Mineral fertilisation had a clear positive effect on yields of the first crop, whereas there were no considerable differences between treatments for the last crop owing to a significant positive effect of green manure incorporation on yields. Although there was a trend of lower mineral $\mathrm{N}$ leaching from organically fertilised soils (organic management: $24.2 \mathrm{~kg} \mathrm{Nha}^{-1}$; conventional management: 28.6), differences in $\mathrm{N}$ losses were not statistically significant between treatments. This shows that under the experimental conditions, leaching losses and crop yields were more strongly influenced by crop rotation and green manuring than by the presence or absence of mineral fertilisation. Overall, the study highlights the benefits of including a green manure in the crop rotation of any farming system.

Keywords past and current crop management; organic and conventional farming practices; green manure; intact monolith lysimeters; mineral $\mathrm{N}$ leaching; crop yield

\section{INTRODUCTION}

Amongst other goals, organic farming practices aim to increase environmental sustainability of farming by reducing pesticide residues on crops, improving biodiversity in the soil, avoiding leaching losses and run-off, and reducing soil erosion by enhancing soil structure (e.g., Lampkin 1994; BioGro New Zealand 2002; IFOAM 2005). Lower nitrate leaching losses have been measured under organic compared to conventional farming systems resulting from lower nitrogen $(\mathrm{N})$ inputs and/or lower stocking densities (Dalgaard et al. 1998; Shepherd et al. 2003). However, alternative farming systems may not be 
sustainable per definitionem. Incorporation of leys, legumes or animal manures, for example, can lead to a nitrate surplus and cause leaching or run-off (Greenland 2000). In some studies no differences or negative effects (e.g., higher leaching losses) of organic management systems were observed when assessing the parameters per unit of yield (Stolze et al. 2000). Most of these findings are site specific, i.e., the system response depends on the particular climate, soil type, and management strategies. This limits our ability to extrapolate from the results and draw conclusions for sites with different soil types and environmental conditions, which means it is necessary to validate the conclusions for different environments including New Zealand (Condron et al. 2000). Moreover, most lysimeter studies have examined leaching losses from grassland systems (e.g., Fraser et al. 1994; Di et al. 1998; Riley et al. 2002; Toor et al. 2005) and only a limited number have studied losses from cropping soils (e.g., Eriksen et al. 1999; Bergström \& Kirchmann 2004).

To reduce overall differences in relevant soil properties that can affect nitrate leaching, intact monolith lysimeters were taken from areas with different farming histories under the same environmental conditions. The lysimeters had the same soil type and were managed under the same crop rotation, which included a leguminous green manure. The practice of year-round grazing in New Zealand is contrasting to European production systems, where livestock are overwintered inside producing large quantities of manure that can be applied to cash crops (Condron et al. 2000). This

Table 1 Chemical and physical soil properties of BHU (site farmed organically for 25 years) and LCF (site farmed conventionally for over 100 years) topsoil samples $(0-15 \mathrm{~cm})$ taken before the start of the lysimeter experiment.

\begin{tabular}{lll}
\hline Soil property & BHU & LCF \\
\hline $\mathrm{C}\left(\mu \mathrm{g} \mathrm{g}^{-1}\right)$ & 0.27 & 0.29 \\
$\mathrm{~N}\left(\mu \mathrm{g} \mathrm{g}^{-1}\right)$ & 0.0024 & 0.0024 \\
$\mathrm{~S}\left(\mu \mathrm{g} \mathrm{g}^{-1}\right)$ & 260 & 300 \\
$\mathrm{pH}$ & 6.1 & 5.7 \\
Total P $\left(\mu \mathrm{g} \mathrm{g}^{-1}\right)$ & 813 & 771 \\
$\mathrm{CEC}\left(\mathrm{cmol}_{\mathrm{c}} \mathrm{kg}^{-1}\right)$ & 14 & 14 \\
$\mathrm{Ca}\left(\mathrm{cmol}_{\mathrm{c}} \mathrm{kg}^{-1}\right)$ & 7.3 & 7.0 \\
$\mathrm{Mg}\left(\mathrm{cmol}_{\mathrm{c}} \mathrm{kg}^{-1}\right)$ & 0.79 & 0.56 \\
$\mathrm{~K}\left(\mathrm{cmol}_{\mathrm{c}} \mathrm{kg}^{-1}\right)$ & 0.76 & 0.39 \\
$\mathrm{Na}\left(\mathrm{cmol}_{\mathrm{c}} \mathrm{kg}^{-1}\right)$ & 0.17 & 0.19 \\
Water holding capacity (\%) (w:w) & 27.2 & 31.6 \\
Bulk density (g cm & \\
\hline
\end{tabular}

highlights the importance of green manure crops and the dependence on biological processes to supply sufficient amounts of $\mathrm{N}$ to crops, especially in organic farming systems in New Zealand. However, including green manures in crop rotations is considered good management practice in any agricultural production system because of their many positive effects on soil fertility and quality. By fixing atmospheric $\mathrm{N}$ and adding organic material to the soils, legumes help build and maintain soil fertility, improve the soil structure and water retention capacity, help suppress plant diseases and support the soil microbial population (Doran et al. 1988; Shepherd et al. 2000; Watson et al. 2002). To evaluate the effect of farming history and current crop management on mineral $\mathrm{N}$ losses, leachate was collected repeatedly from the lysimeters and total mineral $\mathrm{N}$ concentrations were measured. In addition, dry matter yield and $\mathrm{N}$ content of each crop was determined.

\section{MATERIALS AND METHODS}

\section{Site description and weather conditions}

Lysimeters were collected from two sites (c. $2 \mathrm{~km}$ apart) under the same environmental conditions within the Lincoln University Cropping Farm,

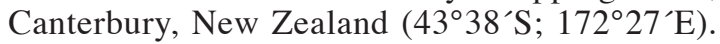
The soil at both sites was a Wakanui silt loam (Mottled Immature Pallic Soil, NZ classification; Udic Ustochrept, USDA) with broadly comparable fertility levels. Some chemical and physical topsoil $(0-15 \mathrm{~cm})$ properties of the two sites are presented in Table 1. At the time of sampling, one site had been farmed organically for 25 years (BHU), and the other conventionally for over 100 years (LCF).

The BHU lysimeters were from a low input area that had been under a 6-year rotation until 1999 and had been under herb-ley (14 species including perennial ryegrass (Lolium perenne), chicory (Cichorium intybus), lucerne (Medicago sativa), red clover (Trifolium pratense), and white clover (Trifolium repens)) between 1999 and the time of sampling in 2001. The rotation included a 1-year mixed herb-ley followed by potatoes (Solanum tuberosum) or Brassica spp., Allium spp., corn (Zea mays), beans (Phaseolus vulgaris), squash (Cucurbita spp.), beet (Beta vulgaris), and lettuce (Lactuca sativa). There are no records of any inversion ploughing and most of the residues were left on the surface. The area had never been grazed, nor had it received any mineral fertilisers or pesticides. 
The LCF site had been under pasture for almost 2 years when the lysimeters were taken and before that had been under an 8-year rotation including oats (Avena sativa) for grazing, spring wheat (Triticum aestivum), barley (Hordeum vulgare), ryegrass (Lolium perenne), vining peas (Pisum sativum), and pasture. During the rotation, residues were incorporated to a depth of $15 \mathrm{~cm}$ by ploughing. The total average annual amount of $\mathrm{N}$ applied during the 8-year rotation was $70 \mathrm{~kg} \mathrm{~N}$ per ha, and a total of $16 \mathrm{~kg}$ phosphorus (P) per ha and year was applied (mainly as water-soluble monocalcium phosphate).

During the trial period, weather conditions at Lincoln deviated from the long-term means on several occasions (Fig. 1). In 2003, rainfall was well below average for most of the year and, in 2002 and 2004, precipitation was less than average for the winter period.

\section{Lysimeter collection and experimental design}

In November 2001, eight replicate intact monolith lysimeters $(50 \mathrm{~cm}$ diam., $70 \mathrm{~cm}$ deep) in steel casings were taken from each site, and installed in the Lincoln University field lysimeter laboratory according to the protocol established (Cameron et al. 1992; Di \& Cameron 2002a). For 5 months before data collection, the lysimeters were maintained under their original plant cover (mixed herb-ley (BHU) and pasture (LCF)) and were irrigated on a regular basis to maintain soil moisture levels adequate for plant growth. Four lysimeters from BHU and four from LCF were randomly placed on either side of the lysimeter trench (c. $1.5 \mathrm{~m}$ wide) and treatments were allocated to the lysimeters randomly on each site of the trench (Fig. 2).

In April 2002, the original cover was sprayed off with glyphosate (2-(phosphonomethylamino) acetic acid) (CON) or cut (ORG) and cultivated to $15 \mathrm{~cm}$. For the following 3 years, four lysimeters from each site were managed under the original production system, while the other four were managed under the alternative management system, i.e., conventional lysimeters were converted to an organic system and organic ones were re-converted to conventional cropping. This resulted in four treatments distinguished by farm management history and current management practices (Fig. 2).

To minimise all differences possibly affecting soil processes, the same cropping regimes were chosen for all treatments consisting of three main crops (barley (H. vulgare), maize (Z. mays), rape (Brassica napus L. ssp. oleifera)) and a lupin green manure (Lupinus angustifolius L.). Over $2^{1 / 2}$ years, a total of $720 \mathrm{~mm}$ of irrigation was applied by hand according to crop requirements and time of year, usually 20 or $25 \mathrm{~mm}$ at a time. Hand weeding was carried out for all treatments and application of pesticides proved unnecessary for the duration of the trial. The conventionally managed lysimeter were fertilised using a commercially available mineral fertiliser $(15 \mathrm{~N} / 10 \mathrm{P} / 10 \mathrm{~K} / 8 \mathrm{~S})$ as well as urea $(46 \% \mathrm{~N})$ following the recommended fertilisation regime as used on the Lincoln University Cropping Farm, while under organic management only fertilisers approved by the New Zealand organic certification agency BioGro were applied (BioGro New Zealand 2001) (amounts as outlined in Table 2). The organically managed lysimeters did not receive any additional $\mathrm{N}$ and were fertilised with reactive rock phosphate (8.7\% P), Patentkali (25K/17S/6 Mg), and elemental sulphur $(100 \% \mathrm{~S})$ at amounts equivalent to those applied to the conventional lysimeters.

\section{Leachate collection}

Leachate was collected from the lysimeters after irrigation or significant rainfall events. After establishing total leachate volume, a $100 \mathrm{ml}$ subsample was taken, filtered through a $0.45 \mu \mathrm{m}$ micropore filter

Table 2 Cultivars, management practices and fertilisation (NPKS in $\mathrm{kg} \mathrm{ha}^{-1}$ ) for crops (barley, Hordeum vulgare; lupin, Lupinus angustifolius; maize, Zea mays; rape, Brassica napus ssp. oleifera) grown in lysimeters.

\begin{tabular}{lcccc}
\hline & Barley & Lupin & Maize & Rape \\
\hline Cultivar & County & Fest & Elita (hybrid) & Winfred \\
Sowing rate $\left(\mathrm{kg} \mathrm{ha}^{-1}\right)$ & 120 & 200 & 50 & 3 \\
Sowing date & 23 May 2002 & 9 Mar 2003 & 11 Nov 2003 & 3 Apr 2004 \\
$\begin{array}{l}\text { Harvest or } \\
\text { incorporation date }\end{array}$ & 29 Jan 2003 & 18 Sep 2003: app. 400 kg N & 8 Mar 2004 & 19 Oct 2004 \\
$\begin{array}{l}\text { NPKS fertilisation } \\
\text { conventional }\end{array}$ & ha ${ }^{-1}$ added to all treatments & & \\
$\quad$ organic & 120/35/35/27 & not fertilised & $80 / 27 / 27 / 21$ & not fertilised \\
date & 0/35/35/27 & not fertilised & $0 / 27 / 27 / 21$ & not fertilised \\
& Aug 2002 & n/a & Nov 2003 & n/a \\
\hline
\end{tabular}




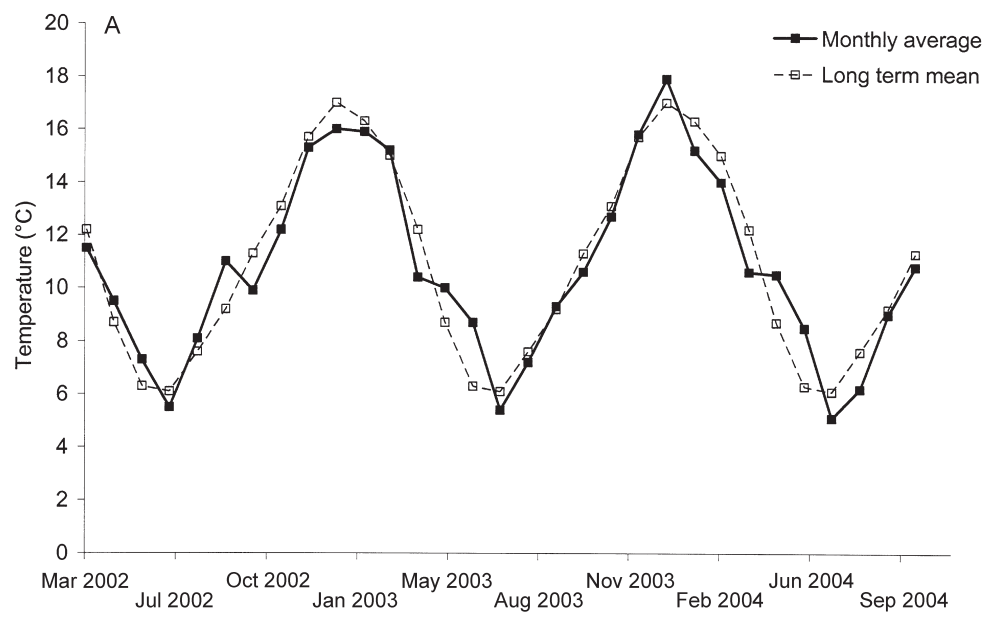

Fig. 1 Monthly average and longterm means for: $\mathbf{A}$, temperature $\left({ }^{\circ} \mathrm{C}\right)$; and $\mathbf{B}$, rainfall $(\mathrm{mm})$ during the course of the lysimeter experiment (Apr 2002-Oct 2004).

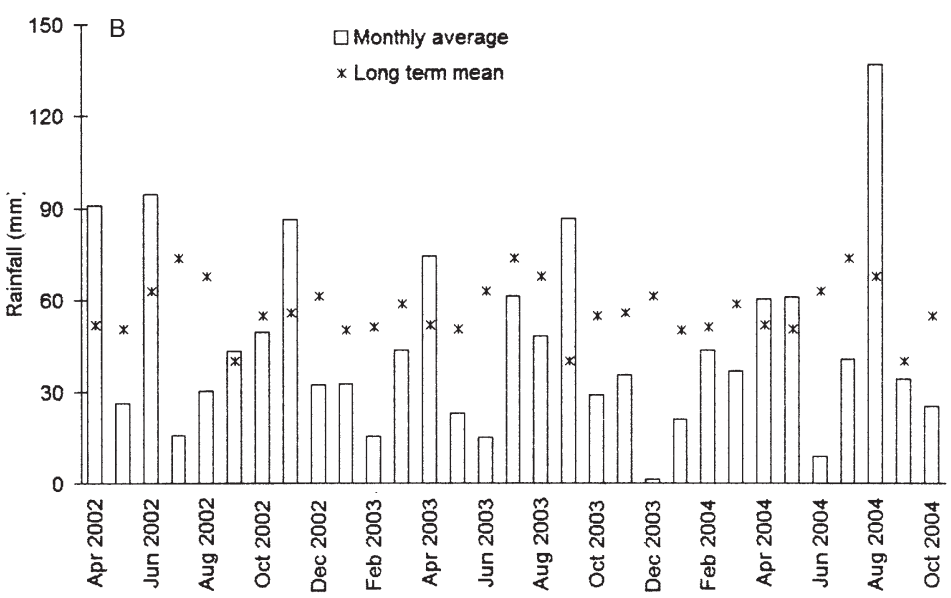

Table 3 Dry matter yield (DMY) $\left(\mathrm{t} \mathrm{ha}^{-1}\right)$ for each crop (barley, Hordeum vulgare; lupin, Lupinus angustifolius; maize, Zea mays; rape, Brassica napus ssp. oleifera), cumulative DMY $\left(\mathrm{t} \mathrm{ha}^{-1}\right)$ and cumulative $\mathrm{N}$ content $\left(\mathrm{kg} \mathrm{ha}^{-1}\right)$ of all four crops grown as part of a $2 \frac{1}{2}$ year crop sequence in lysimeters. (Values are means (standard errors of means); $n=4$.)

\begin{tabular}{lcccccc}
\hline Treatments & Barley DMY & Lupin DMY & Maize DMY & Rape DMY & $\begin{array}{c}\text { Cumulative } \\
\text { DMY }\end{array}$ & $\begin{array}{c}\text { Cumulative N } \\
\text { content }\end{array}$ \\
\hline BHU-Con & $8.96(0.27)$ & $17.19(1.39)$ & $14.40(0.51)$ & $2.76(0.26)$ & $43.3(1.89)$ & $737.4(41.7)$ \\
BHU-Org & $5.33(0.11)$ & $20.74(3.35)$ & $14.16(0.39)$ & $2.78(0.13)$ & $43.0(3.53)$ & $762.4(92.9)$ \\
LCF-Con & $10.35(0.29)$ & $15.78(2.27)$ & $12.76(0.76)$ & $2.76(0.27)$ & $41.6(3.41)$ & $606.6(57.1)$ \\
LCF-Org & $6.14(0.43)$ & $14.57(3.06)$ & $10.77(1.09)$ & $3.07(0.21)$ & $34.6(3.89)$ & $530.1(91.5)$ \\
LSD $_{0.05}$ & 0.92 & 8.11 & 2.28 & 0.69 & 10.1 & 228.6 \\
\hline
\end{tabular}

to remove suspended particles before analysis for nitrate $\left(\mathrm{NO}_{3}{ }^{-}\right)-\mathrm{N}$, ammonium $\left(\mathrm{NH}_{4}{ }^{+}\right)-\mathrm{N}$ and nitrite $\left(\mathrm{NO}_{2}{ }^{-}\right)-\mathrm{N}$ by Flow Injection Analysis (Tecator, Sweden). If immediate sample processing was not possible, the samples were frozen until analysis was carried out.

\section{Statistical analysis}

All data was analysed by general linear model analysis of variance using GenStat Release 7.1. Samples were considered significantly different when $P<0.05$ and least significant differences $\left(\mathrm{LSD}_{0.05}\right)$ were calculated. 


\section{RESULTS}

\section{Dry matter yield and crop $\mathbf{N}$ content}

The lysimeters originating from LCF (LCF-Org and LCF-Con $)(P=0.003)$ and the lysimeters managed conventionally during the study (BHUCon and LCF-Con) $(P<0.001)$ showed significantly higher dry matter yields (DMY) for the first crop, barley, compared with those from BHU and those managed organically during this study (Table 3 ). The differences in dry matter yields of maize and lupin were less pronounced between BHU and LCF. However, maize showed higher yields when grown in BHU soils $(P=0.005)$. There was a strong positive correlation between the maize and lupin yields $\left(R^{2}=0.742\right)$. Rape yields did not show any variation among treatments (Table 3 ). The overall (cumulative) crop yield revealed no significant differences among the four treatments (Table 3).

Nitrogen content in barley (in $\mathrm{kg} \mathrm{ha}^{-1}$ ) was significantly higher under conventional management (BHU-Con and LCF-Con) $(P<0.001)$ whereas no significant differences could be found relating to past management (BHU versus LCF). Lupin and maize, in contrast, showed significantly higher $\mathrm{N}$ content in the soils from the BHU under both management types (BHU-Org and BHU-Con) $(P=0.048$ and 0.003 for lupin and maize, respectively). In rape, $\mathrm{N}$ levels did not differ significantly between current and past farming practices. The cumulative $\mathrm{N}$ content (Table 3) was highest for BHU crops (average of 750 compared to $568 \mathrm{~kg} \mathrm{ha}^{-1}$ for LCF), with BHUOrg and BHU-Con showing similar values. Crops subjected to the LCF-Org treatment had the lowest $\mathrm{N}$ content, although the difference was only significant between BHU-Org and LCF-Org.

\section{Effect of past and current management on mineral $\mathbf{N}$ leaching}

Figure 3 shows that the concentration of mineral $\mathrm{N}$ in the leachate varied during the course of the experiment. The highest values were measured for BHU-Con and the lowest for LCF-Org (up to 35 and $23 \mathrm{mg} \mathrm{N}$ litre $^{-1}$, respectively). A connection between fertilisation or cultivation events and mineral $\mathrm{N}$ concentration could be observed with the general trends of the $\mathrm{N}$ concentrations in the leachate decreasing when the lysimeters were under crop, and increasing after soil cultivation (April 2002, February 2003, November 2003, and March 2004) and fertilisation (September and November 2003).

Table 4 shows the cumulative amounts of drainage and total mineral $\mathrm{N}$ in the leachate that was collected from the lysimeters over $2 \frac{1}{2}$ years. Although average drainage volume and mineral $\mathrm{N}$ content were highest in the first of the three periods (year $1>$ year $2>$ year 3 for $\mathrm{N}$; year $1>$ year $3>$ year 2 for drainage), there were no significant differences that can be attributed to past or current management. On average, BHU as well as the currently organically fertilised lysimeters had higher drainage in all three periods. In year 1, mineral $\mathrm{N}$ losses were higher from LCF lysimeters (mean of 12.3 compared to $8.5 \mathrm{~kg} \mathrm{ha}^{-1}$ for BHU) and CON (mean of 12.7 versus $8.2 \mathrm{~kg} \mathrm{ha}^{-1}$ for ORG). Overall, all treatments showed comparable leaching

Table 4 Mean cumulative drainage $(\mathrm{mm})$ and mineral nitrogen $(\mathrm{N})$ leached $\left(\mathrm{kg} \mathrm{ha}^{-1}\right)$ between April 2002 and October 2004. $\left(\mathrm{NO}_{3}{ }^{-}-\mathrm{N}\right.$ constituted $97-98.8 \%, \mathrm{NH}_{4}{ }^{+}-\mathrm{N} 0.9-2.2 \%$, and $\mathrm{NO}_{2}{ }^{-}-\mathrm{N} 0.16-0.7 \%$ of total mineral $\mathrm{N}$ leached; $n=4$; SEM, standard errors of means; range, range of values measured.)

\begin{tabular}{|c|c|c|c|c|c|c|c|}
\hline \multirow[b]{2}{*}{ Treatments } & \multicolumn{2}{|c|}{ Year 1 (Apr 2002-Apr 2003) } & \multicolumn{2}{|c|}{ Year 2 (Apr 2003-Apr 2004) } & \multicolumn{2}{|c|}{ Year 3 (Apr 2004-Oct 2004) } & \multirow{2}{*}{$\begin{array}{c}\text { Total } \\
\text { Mean (SEM) }\end{array}$} \\
\hline & Mean (SEM) & Range & Mean (SEM) & Range & Mean (SEM) & Range & \\
\hline \multicolumn{8}{|c|}{ Drainage (mm) } \\
\hline BHU-Con & $167.0(3.4)$ & $157-172.5$ & $93.8(18.4)$ & $64.5-170$ & $159.9(6.9)$ & $148-179$ & $421(25.6)$ \\
\hline LCF-Con & $152.9(7.9)$ & $142-193$ & $66.1(3.0)$ & $60-70.8$ & $128.4(15.2)$ & $85.5-157.5$ & $347(16.2)$ \\
\hline BHU-Org* & $156.1(33.4)$ & $57.8-200$ & $80.8(29.5)$ & $16.8-81.5$ & $144.4(29.6)$ & $56-178.5$ & $444(84.9)$ \\
\hline LCF-Org & $167.1(11.4)$ & $132-170.3$ & $102.1(15.6)$ & $70.8-144.5$ & $165.1(3.3)$ & $158.5-172$ & $434(17.0)$ \\
\hline $\mathrm{LSD}_{0.05}$ & 55.9 & & 58.9 & & 52.6 & & 141.3 \\
\hline \multicolumn{8}{|c|}{ Mineral $\mathbf{N}\left(\mathrm{kg} \mathrm{ha}^{-1}\right)$} \\
\hline BHU-Con & $11.6(0.57)$ & $10.3-12.6$ & $11.7(3.05)$ & $6.1-19.9$ & $5.7(2.91)$ & $2.7-14.5$ & $29.1(2.74)$ \\
\hline LCF-Con & $13.7(3.16)$ & $7.0-21.7$ & $8.9(1.02)$ & $7.3-11.8$ & $5.4(2.34)$ & $1.3-12.0$ & $28.0(4.66)$ \\
\hline BHU-Org & $5.4(0.93)$ & $3.7-5.9$ & $9.1(1.95)$ & $4.0-13.2$ & $6.3(0.22)$ & $2.5-8.1$ & $20.8(2.75)$ \\
\hline LCF-Org & $11.0(1.96)$ & $5.7-15.0$ & $11.2(1.50)$ & $7.0-14.1$ & $5.4(1.10)$ & $2.4-7.2$ & $27.6(3.18)$ \\
\hline $\mathrm{LSD}_{0.05}$ & 6.21 & & 6.24 & & 6.32 & & 10.9 \\
\hline
\end{tabular}

${ }^{*}$ Large standard errors for BHU-Org are a result of low drainage from one replicate lysimeter. 


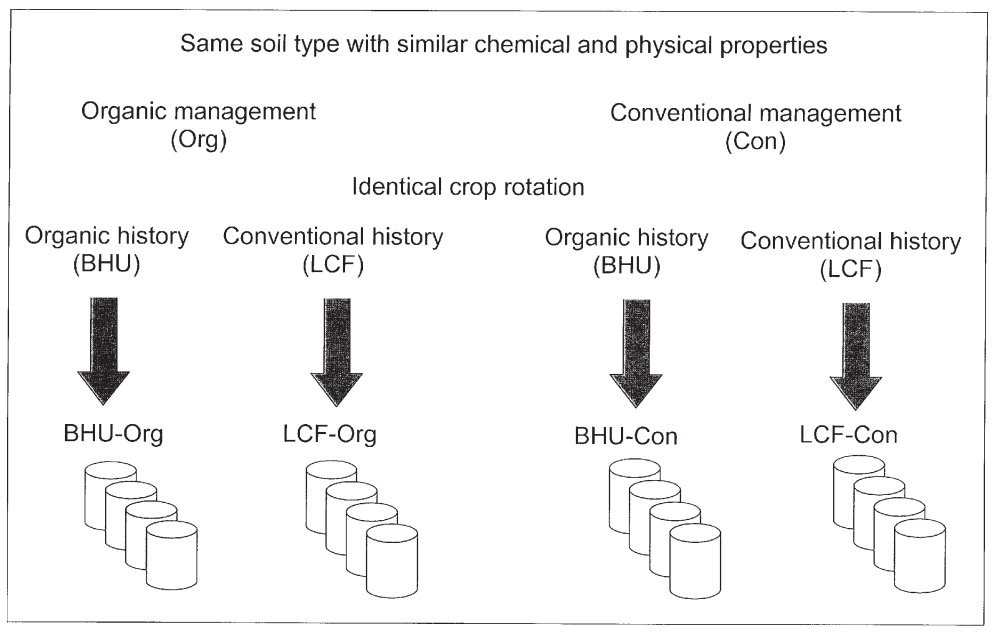

Fig. 2 Schematic representation of the lysimeter trial setup.

Fig. 3 (below) Mean concentration (mg litre $\left.{ }^{-1}\right)$ of mineral nitrogen $(\mathrm{N})( \pm$ standard errors $)$ in leachate collected from lysimeters between April 2002 and October 2004. (Diamonds, time of crop sowing; squares, time of crop harvest; arrows represent times of fertilisation and lupin incorporation (see Table 2 for exact dates and amounts). $(n=4$.)

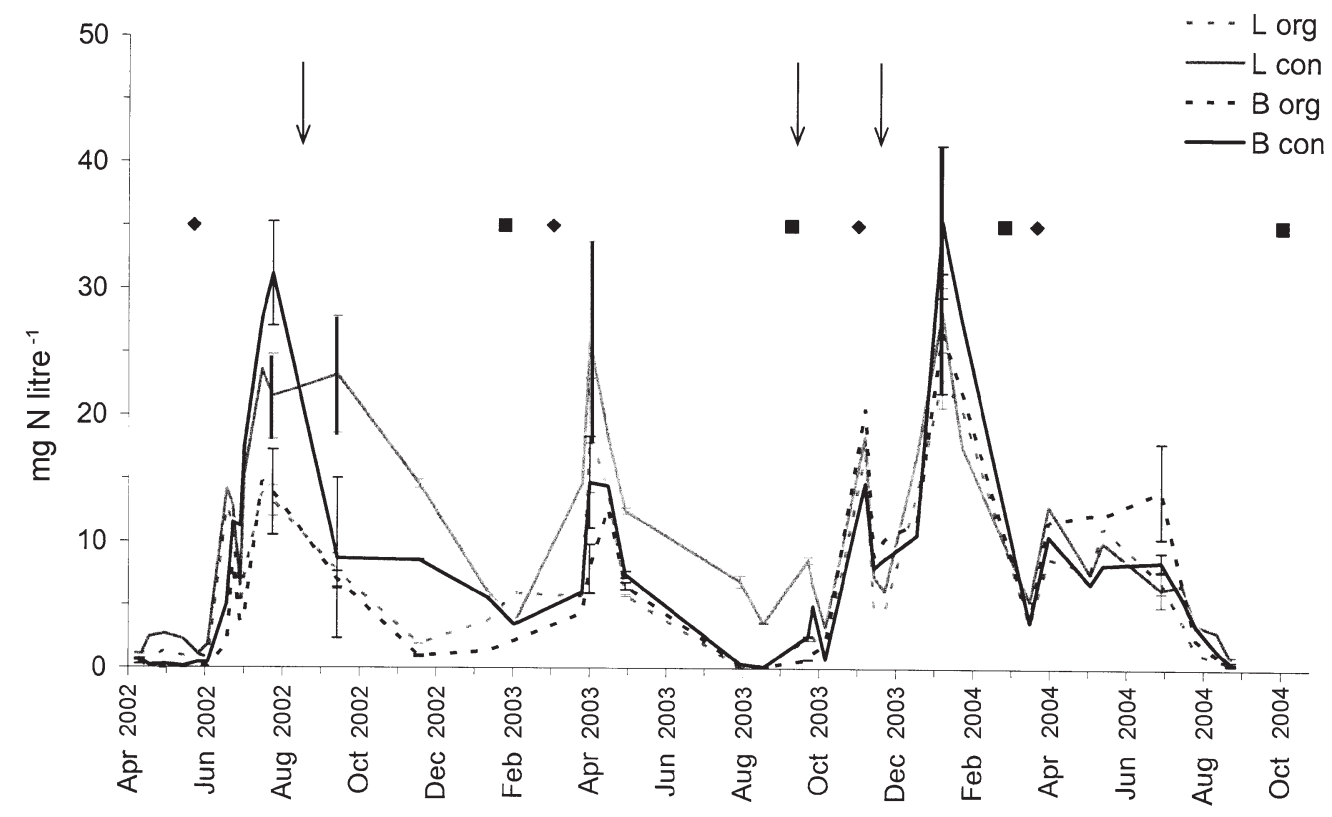

losses. In year 2 , leaching losses ranged from 8.9 to $11.7 \mathrm{~kg} \mathrm{ha}^{-1}$ with a mean of $10.2 \mathrm{~kg} \mathrm{ha}^{-1}$, whereas in year 3 the range was $5.4-6.3 \mathrm{~kg} \mathrm{ha}^{-1}$ (mean: $5.7 \mathrm{~kg}$ $\left.\mathrm{ha}^{-1}\right)$.

Drainage from lysimeter 6 (BHU-Org treatment) was much lower than from the other replicates of the treatment which resulted in large standard errors for the BHU-Org drainage means (standard errors for mineral $\mathrm{N}$ loss are similar to those observed for the other treatments) (Table 4). Over the entire trial period, cumulative $\mathrm{NO}_{3}{ }^{-}-\mathrm{N}$ losses were similar for BHU-Con, LCF-Con, and LCF-Org whereas slightly lower amounts were leached from BHU-Org lysimeters compared to the other treatments.

\section{DISCUSSION}

The present study was not based on a systematic whole-farm approach and was not a comparison of farming systems as such. It was instead focusing on how specific farming practices affect mineral $\mathrm{N}$ losses and crop yields. In particular, it aimed to assess the effects of past and current organic 
and conventional management practices (crop rotation, green manuring, conventional and organic fertilisation) and the result of altering the existing system, i.e., conversion or re-conversion to organic and conventional management, respectively. As microbially mediated soil processes, such as $\mathrm{N}$ mineralisation and consequently nitrate leaching, are influenced by inherent soil properties, environmental conditions and anthropogenic activities (O'Donnell et al. 2001), it was important to reduce such external differences between the two systems by choosing two sites of the same environmental conditions and the same soil type and then to subject the soils to the same crop rotation.

The influence of previous (LCF versus BHU) and current (CON versus ORG) management practices was most pronounced for the first crop (barley). The difference in yield ( $\mathrm{LCF}>\mathrm{BHU}$ ) might be a result of the different fertilisation regimes before the lysimeters were taken. Although both soils were in a restorative phase in the years leading up to this experiment (pasture and herb-ley for LCF and BHU, respectively), the LCF site was grazed and had been cultivated and fertilised before the pasture phase. In contrast, the BHU area was a low input area and had not been actively managed for c. 3 years before the lysimeters were taken. Hence, it is likely that the LCF soils responded better to the conventional fertilisation (also seen in LCF-Con>BHU-Con) because the microbial community was adapted to this form of nutrient input (Barkle et al. 2001). The higher yields found under conventional management are not surprising and reflect the difference in the amount of $\mathrm{N}$ fertilisation applied.

Although the subsequent crops showed only minor differences in dry matter yields between BHU and LCF treatments, maize yields were significantly higher when grown in BHU soils, despite addition of $\mathrm{N}$ in CON. The strong positive correlation between the maize and lupin yields indicates that maize growth was affected by the addition of the green manure crop, which had slightly higher yields in BHU soils. These soils were, therefore, supplied with more carbon (C) and $\mathrm{N}$ by addition of greater amounts of organic matter. The effect was particularly evident for the maize yield in the unfertilised BHU treatment (BHU-Org). Rape yields were similar for all treatments, indicating that the positive influence of the green manure crop on the unfertilised treatments was still noticeable a year after incorporation.

Overall, differences in dry matter yields and $\mathrm{N}$ content were small (Table 3). Although there was a clear positive effect of $\mathrm{N}$ fertilisation $(\mathrm{CON}>\mathrm{ORG}$ for both soils), the treatment under continued organic management (BHU-Org) responded better to the lack of fertilisation and amendment with organic matter than the treatment that had been converted to organic management as part of the experiment (LCFOrg), i.e., conversion to organic farming practices resulted in lower crop yields. Crop yields may increase only after 3-5 years following conversion to organic practices, whereas similar yields were found when comparing sites under long-term organic or conventional management (Altieri 1995; Drinkwater et al. 1995; Reganold et al. 2001). This suggests that lower crop yields during the first few years following conversion can be overcome when soils have been under long-term organic management (like BHUOrg) (Bulluck et al. 2002). This might be related to changes in soil properties resulting from beneficial effects of organic farming practices that allow for better and faster response to organic matter addition and make it possible for the soils to maintain higher fertility despite lack of fertilisation (Robertson \& Morgan 1996; Shepherd et al. 2000; Bulluck et al. 2002).

There were no significant differences in mineral $\mathrm{N}$ losses between treatments, which indicates that the application of inorganic fertilisers did not result in an increase in $\mathrm{N}$ leaching. Several studies have shown that organic farming practices can reduce nitrate leaching (Dalgaard et al. 1998; e.g., Stolze et al. 2000; Stopes et al. 2002), whereas others stress that mineral $\mathrm{N}$ losses can be equal or higher from organic farms. Application of animal manures or incorporation of green manures can result in $\mathrm{N}$ flushes owing to sudden mineralisation of the organic material (Eriksen et al. 1999; Shepherd et al. 2003). Fraser et al. (1988) reported higher autumn levels of nitrate in soils that received animal manure compared with chemical fertilisers, and attributed this difference to increased mineralisation. This can be a problem when cultivation coincides with warm temperatures (stimulating mineralisation) followed by heavy rain (increasing drainage) or when manures are applied in late autumn when evapotranspiration rates are low and $\mathrm{N}$ released from organic matter is lost from the soil by leaching (Di et al. 1999; Shepherd et al. 2003).

In this study, the amounts of annual $\mathrm{N}$ leaching observed (1.3-20 kg ha-1) are comparable to those reported in other studies (Di \& Cameron 2002b; Stopes et al. 2002), indicating that addition of $\mathrm{N}$ in mineral form had no effect on the leaching patterns nor did incorporation of a leguminous green manure 
drastically increase mineral $\mathrm{N}$ losses. This might have been a consequence of the lower than average rainfall during the trial period resulting in less drainage than expected for this geographical area. However, in accordance with our results, Stopes et al. (2002) reported similar or smaller losses from organically managed sites compared to conventional systems when under similar cropping. In addition, Drinkwater et al. (1998) and Bergström \& Kirchmann (2004) showed that the inclusion of green manure crops in the cropping sequence can improve soil $\mathrm{N}$ retention and, consequently, reduce losses.

\section{CONCLUSIONS}

By collecting leachate samples from the lysimeters, the influence of mineral versus organic fertilisers and the effect of a leguminous green manure on mineral $\mathrm{N}$ leaching and crop yield were established. Results showed that the application of a mineral fertiliser significantly increased yields of the first crop (barley), whereas the incorporation of a lupin green manure had a positive effect on dry matter yields of subsequent crops. No significant differences were observed in the amount of mineral $\mathrm{N}$ leached from organically and conventionally managed soils. Therefore, mineral fertilisation had a negligible effect on mineral $\mathrm{N}$ leaching under the experimental conditions and leaching losses were strongly influenced by crop rotation and green manuring, the farming practices that were the same for all treatments. Owing to apparent positive effects on yields and mineral $\mathrm{N}$ leaching, including green manures in the crop rotation is advisable in any production system.

\section{ACKNOWLEDGMENTS}

We are grateful for the technical assistance provided by Lincoln University Analytical Services. Special thanks to Andrew McLachlan for his advice regarding the statistical analysis of the data and to Trevor Hendry for writing and customising macros to process the leachate data. We also thank Rhys Minchin, Neil Smith, and Roger McLenaghen for practical help and advice. Financial support for this study was provided by the New Zealand Fertiliser Manufacturers' Research Association and Lincoln University.

\section{REFERENCES}

Altieri MA 1995. Agroecology. The Science of sustainable agriculture. 2nd ed. Boulder, United States, Westview Press. 433 p.

Barkle GF, Stenger R, Sparling GP, Painter DJ 2001. Immobilisation and mineralisation of carbon and nitrogen from dairy farm effluent during laboratory soil incubations. Australian Journal of Soil Research 39(6): 1407-1417.

Bergström L, Kirchmann H 2004. Leaching and crop uptake of nitrogen from nitrogen-15-labeled green manures and ammonium nitrate. Journal of Environmental Quality 33(5): 1786-1792.

BioGro New Zealand 2001. BioGro New Zealand Organic Standards. http://www.biogro.co.nz/main. php?page $=170$ (accessed 26 April 2005).

BioGro New Zealand 2002. BioGro NZ Guide for Conversion to Organic Production. http://www. bio-gro.co.nz/content/files/Vegetables\%20Cro p\%20Guide\%20021021.pdf (accessed 7 April 2006).

Bulluck LR, III, Brosius M, Evanylo GK, Ristaino JB 2002. Organic and synthetic fertility amendments influence soil microbial, physical and chemical properties on organic and conventional farms. Applied Soil Ecology 19(2): 147-160.

Cameron KC, Smith NP, McLay CDA, Fraser PM, McPherson PJ, Harrison DF, Harbottle P 1992. Lysimeters without edge-flow: an improved design and sampling procedure. Soil Science Society of America Journal 56: 1625-1628.

Condron LM, Cameron KC, Di HJ, Clough TJ, Forbes EA, McLaren RG, Silva RG 2000. A comparison of soil and environmental quality under organic and conventional farming systems in New Zealand. New Zealand Journal of Agricultural Research 43(4): 443-466.

Dalgaard T, Halberg N, Kristensen IS 1998. Can organic farming help to reduce $\mathrm{N}$-losses? Nutrient cycling in Agroecosystems 52(2-3): 277-287.

Di HJ, Cameron KC 2002a. The use of nitrification inhibitor, dicyandiamide (DCD), to decrease nitrate leaching and nitrous oxide emissions in a simulated grazed and irrigated grassland. Soil Use \& Management 18(4): 395-403.

Di HJ, Cameron KC 2002b. Nitrate leaching in temperate agroecosystems: sources, factors and mitigating strategies. Nutrient Cycling in Agroecosystems 64(3): 237-256.

Di HJ, Cameron KC, Moore S, Smith NP 1998. Nitrate leaching and pasture yields following the application of dairy shed effluent or ammonium fertilizer under spray or flood irrigation: results of a lysimeter study. Soil Use \& Management 14(4): 209-214. 
Di HJ, Cameron KC, Moore S, Smith NP 1999. Contributions to nitrogen leaching and pasture uptake by autumn-applied dairy effluent and ammonium fertilizer labeled with ${ }^{15} \mathrm{~N}$ isotope. Plant \& Soil 210(2): 189-198.

Doran JW, Fraser DG, Culik MN, Liebhardt WC 1988. Influence of alternative and conventional agricultural management on soil microbial processes and nitrogen availability. American Journal of Alternative Agriculture 2: 99-106.

Drinkwater LE, Letourneau DK, Workneh F, van Bruggen AHC, Shennan C 1995. Fundamental differences between conventional and organic tomato agroecosystems in California. Ecological Applications 5(4): 1098-1112.

Drinkwater LE, Wagoner P, Sarrantonio M 1998. Legumebased cropping systems have reduced carbon and nitrogen losses. Nature 396(6708): 262-265.

Eriksen J, Askegaard M, Kristensen K 1999. Nitrate leaching in an organic dairy/ crop rotation as affected by organic manure type, livestock density and crop. Soil Use \& Management 15(3): 176-182.

Fraser DG, Doran JW, Sahs WW, Lesoing GW 1988. Soil microbial populations and activities under conventional and organic management. Journal of Environmental Quality 17(4): 585-590.

Fraser PM, Cameron KC, Sherlock RR 1994. Lysimeter study of the fate of nitrogen in animal urine returns to irrigated pasture. European Journal of Soil Science 45(4): 439-447.

Greenland D 2000. Effects on soils and plant nutrition. In: Tinker PB ed. Shades of green - a review of UK farming systems. Stoneleigh Park, United Kingdom, Royal Agricultural Society of England. Pp. 6-20.

IFOAM 2005. IFOAM homepage. http://www.ifoam. org/index.html (accessed 7 April 2006).

Lampkin N 1994. Organic farming. Ipswich, United Kingdom, Farming Press Books. 715 p.
O’Donnell AG, Seasman M, Macrae A, Waite I, Davies JT 2001. Plants and fertilisers as drivers of change in microbial community structure and function in soils. Plant \& Soil 232(1-2): 135-145.

Reganold JP, Glover JD, Andrews PK, Hinman HR 2001. Sustainability of three apple production systems. Nature 410(6831): 926-930.

Riley GI, Zhao FJ, McGrath SP 2002. Leaching losses of sulphur from different forms of sulphur fertilizers: a field lysimeter study. Soil Use \& Management 18(2): 120-126.

Robertson FA, Morgan WC 1996. Effects of management history and legume green manure on soil microorganisms under 'organic' vegetable production. Australian Journal of Soil Research 34(3): 427-440.

Shepherd M, Harrison R, Cuttle S, Johnson B, Shannon D, Gosling P, Rayns F 2000. Understanding of soil fertility in organically farmed soils. http://www. adas.co.uk/soilfertility/download.html?topid=7 (accessed 26 April 2005).

Shepherd M, Pearce B, Cormack B, Phillipps L, Cuttle S, Bhogal A, Costagin P, Unwin R 2003. An assessment of the environmental impacts of organic farming. http://www.defra.gov.uk/science/ project_data/DocumentLibrary/OF0405/OF0405_ 909_TRP.doc (accessed 26 April 2005).

Stolze M, Piorr A, Häring A, Dabbert S 2000. Environmental impacts of organic farming in Europe. Stuttgart, Germany, University of Hohenheim. 127 p.

Stopes C, Lord EI, Philipps L, Woodward L 2002. Nitrate leaching from organic farms and conventional farms following best practice. Soil Use \& Management 18(S1): 256-263.

Toor GS, Condron LM, Cade-Menun BJ, Di HJ, Cameron KC 2005. Preferential phosphorus leaching from an irrigated grassland soil. European Journal of Soil Science 56(2): 155-167.

Watson CA, Atkinson D, Gosling P, Jackson LR, Rayns FW 2002. Managing soil fertility in organic farming systems. Soil Use \& Management 18 (supplement): 239-247. 